May 2019

\title{
Academic Instruction Librarians' Teacher Identity Development Through Participation in the Scholarship of Teaching and \\ Learning
}

Lauren Hays

MidAmerica Nazarene University, lauhays@ucmo.edu

Bethani Studebaker

Northwest Nazarene University, bstudebaker@nnu.edu

Follow this and additional works at: https://digitalcommons.georgiasouthern.edu/ij-sotl

\section{Recommended Citation}

Hays, Lauren and Studebaker, Bethani (2019) "Academic Instruction Librarians' Teacher Identity Development Through Participation in the Scholarship of Teaching and Learning," International Journal for the Scholarship of Teaching and Learning: Vol. 13: No. 2, Article 4.

Available at: https://doi.org/10.20429/ijsotl.2019.130204 


\title{
Academic Instruction Librarians' Teacher Identity Development Through Participation in the Scholarship of Teaching and Learning
}

\author{
Abstract \\ Teaching is a primary responsibility of many academic librarians. However, despite the job duties, many \\ academic librarians do not see themselves as teachers. To determine how participation in the \\ Scholarship of Teaching and Learning (SoTL) impacted academic instruction librarians' teacher identity \\ the authors conducted an explanatory sequential mixed methods study. Using the theoretical framework, \\ Communities of Practice, results from the quantitative survey demonstrated participation in SoTL did \\ impact academic librarians' teacher identity. The qualitative interviews explained the quantitative data. \\ Study findings have implications for academic developers, Library and Information Science graduate \\ programs, and academic library administrations.
}

\section{Keywords}

Academic Instruction Librarians, Teacher Identity, Scholarship of Teaching and Learning, Communities of Practice

\section{Creative Commons License} cc) (i) $€$

This work is licensed under a Creative Commons Attribution-Noncommercial-No Derivative Works 4.0 License. 
IJ-SoTL, Vol. 13 [2019], N0. 2, Art. 4

\title{
Academic Instruction Librarians' Teacher Identity Development Through Participation in the Scholarship of Teaching and Learning
}

\author{
Lauren Hays' \& Bethani Studebaker ${ }^{2}$ \\ I MidAmerica Nazarene University \\ 2 Northwest Nazarene University
}

Received 30 August 2018;Accepted 27 March 2019

\begin{abstract}
Teaching is a primary responsibility of many academic librarians. However, despite the job duties, many academic librarians do not see themselves as teachers. To determine how participation in the Scholarship of Teaching and Learning (SoTL) impacted academic instruction librarians' teacher identity the authors conducted an explanatory sequential mixed methods study. Using the theoretical framework, Communities of Practice, results from the quantitative survey demonstrated participation in SoTL did impact academic librarians' teacher identity. The qualitative interviews explained the quantitative data. Study findings have implications for academic developers, Library and Information Science graduate programs, and academic library administrations.
\end{abstract}

The Scholarship of Teaching and Learning (SoTL) may be a vehicle through which academic librarians develop a cohesive identity. Previous research has shown that a professional identity is missing from the field of librarianship (Davis, Lundstrom, \& Martin, 20I I; Freedman, 20I4;Walter, 2008). Often, librarians are viewed as caretakers of resources. In the past, this view of librarians was in keeping with the responsibilities of the job. Since Alexandria, librarians have housed, preserved, and made the written word available (Battles, 2003). With the advent of the Information Age, though, librarians' roles have evolved. Specifically, in higher education, the role of librarians has changed tremendously (Drabinski, 20 16; Ellis, Rosenblum, Stratton, \& Ames-Stratton, 20I4).

Today, as part of their job responsibilities, many librarians in colleges and universities teach (Bewick \& Corrall, 2010; Davies-Hoffman, Alvarez, Costello, \& Emerson, 20I3). Despite librarians teaching for over 100 years, the past few decades have led to changes in the skills librarians instruct on and the type of educating librarians conduct (Walter, 2005; Warner \& Seamans, 2004). Indeed, the teaching of information literacy skills is a main job requirement for many academic librarians (Houtman, 2010; Julien, Gross, \& Latham, 2018). However, the responsibility of instruction is only one of the many roles librarians must adopt. The traditional job functions of collection manager and reference work remain a requirement for many academic librarians working today, and library schools still teach those traditional skills (Freedman, 2014; Westbrock \& Fabian, 2010). Therefore, academic librarians struggle with their professional identity due to the numerous roles they must fulfill. Librarians use the services they provide as a marker of their professional identity and altering their professional persona is difficult because librarians are connected to their traditional work responsibilities (Freedman, 20I4; Hicks, 20I6; Zai, 20I4).As a result, the adopted career characteristics of librarians does not always include the role of teacher, despite the fact that teaching is an important requirement for many academic librarians' jobs (Austin \& Bhandol, 20 I3; Wheeler \& McKinney, 20I5).

In this explanatory sequential mixed methods study of how involvement in SoTL impacted academic instruction librarians' teacher identity, the results aid in understanding the value of SoTL as a professional development tool and support the understanding of how involvement in SoTL affects professional identities.A deeper grasp of SoTL's impact on professional identities is a valuable outcome for the broad higher education community and more specifically for academic developers. Gaps still exist in the literature on how SoTL interplays with and influences educational development.

\section{LITERATURE REVIEW}

Many academic librarians identify as a teacher, but many do not (Julien \& Genuis, 20I I). However, a teacher identity is important because it has been linked to teaching effectiveness (Day, 2008; Day \& Kington, 2008). Similar to other graduate programs, teaching is irregularly, and often minimally, included in Library and Information Science curriculums (Hensley, 2015; Houtman, 2010). Studies have shown that librarians do not learn many of the necessary instruction skills during their library school coursework (Saunders, 2015; Westbrock \& Fabian, 2010). Perini (2014) and Bradley (2009) recommended that librarians become involved in SoTL. SoTL is an area of scholarship wherein higher education faculty members study teaching and learning and make the results public (Shulman, 2006). Studies grounded in SoTL research inform the effectiveness of instruction and guide the improvement of teaching methods (Kern, Mettetal, Dixson, \& Morgan, 2015). Opportunely, engagement in SoTL can have an impact on identity when academic freedom is allowed. Similar to librarians, faculty have discipline-specific identities, and a teacher identity is not a guarantee for those working in higher education (Mårtensson, Roxå, \& Olsson, 20I I). Researchers have shown SoTL to be valuable in helping university professors adopt a teacher identity.

In Lave and Wenger's (199I) Situated Learning Theory, communities of practice are a primary characteristic. In this theory, people learn, create meaning, and form identities through their involvement with others in the community (Lave \&Wenger, 1991; Wenger, 1998). Thus, groups of people participating in a system affect how individuals in the group see themselves (Wenger, 1998). Given that identity was a primary focus of this study, the theory of Communities of Practice framed the formation of this study's research methods and the understanding of the results. The authors framed SoTL as an international community of practice. Therefore, the authors sought to understand SoTL's impact on academic instruction librarians' teacher identity. 


\section{Research question}

\section{RQI:What is the impact of the Scholarship of Teaching and Learning on academic instruc- tion librarians' teacher identity?}

\section{METHODS}

To answer the study's question, the authors conducted an explanatory sequential mixed methods study. The primary rationale for a mixed methods approach was complementarity while the second rationale was development (Bryman, 2006; Greene et al., 1989). Using a retrospective pre-post survey design, the authors created original Likert-scale questions as well as, with permission, adapted survey questions from the University of Wisconsin's Teaching and Learning Impact Survey (Meyers, 2007). To validate the survey, the researchers conducted content validity and face validity. During the pilot, and after the collection of all quantitative data, the authors ran Cronbach's alpha to test the reliability of the survey. To ensure the credibility of interviews, the researchers piloted the interview questions with two academic instruction librarians to make sure the questions would lead to relevant data. Then, to validate the findings of the interviews, the researchers used member checking (Marshall \& Rossman, 2016).

\section{Participants}

Prior to this study, the population was unknown. No one had previously identified a specific population of librarians who participated in SoTL. Therefore, a volunteer convenience sample of librarians on the Association of College and Research Libraries listserv was used for the quantitative portion of the study (Teddlie \&Yu, 2007). Ninety-five participants $(n=95)$ of the population finished complete or partial surveys. Survey participants represented a broad range of the academic instruction librarian population. Table I summarizes the survey participant demographics for gender and employment status for both complete and incomplete survey results.

\begin{tabular}{|l|c|c|}
\hline \multicolumn{3}{|l|}{ Table I. Demographic Data of Survey Participants $(n=95)$} \\
\hline Gender & Number & Percent \\
\hline Female & 79 & $83.15 \%$ \\
\hline Male & 13 & $13.68 \%$ \\
\hline Non-binary & $\mathrm{I}$ & $1.05 \%$ \\
\hline I do not wish to self-identify & 2 & $2.1 \%$ \\
\hline Employment Status & Number & Percent \\
\hline Faculty & 63 & $66.32 \%$ \\
\hline Staff & 24 & $25.26 \%$ \\
\hline Other & 8 & $8.42 \%$ \\
\hline Tenure Status & Number & Percent \\
\hline Tenured & 20 & $21.05 \%$ \\
\hline Not Tenured & 43 & $45.26 \%$ \\
\hline Eligible for tenure within 3 years & 12 & $12.63 \%$ \\
\hline
\end{tabular}

Of the 95 librarians who participated in the survey, 40 agreed to be interviewed. These librarians represented a range of experience. After reviewing the demographic data and the survey results, the researcher selected seven academic instruction librarians to interview. Table 2 details the demographics of the interview participants, including gender, employment status, tenure status, institutional status, and length of experience. Interview participants were selected to represent a range of demographics and represent the overall survey population.

\section{ANALYSIS}

The authors used a Wilcoxon signed-rank test to analyze the difference between the participants' responses before and after participation in SoTL. Researchers use a Wilcoxon signed-rank test to study the same population at two different times-before and after an event has occurred (Field, 20I3;Tanner, 20I2). When analyzing the results from the Wilcoxon signed-rank test, the authors reviewed the z-scores, mean ranking, statistical significance, and effect size (Field, 20I3).

To gather the qualitative data, the authors conducted semi-structured interviews with seven librarians $(n=7)$. Interview questions were adapted from Walter's (2008) study on librarians' teacher identity and influenced by the quantitative findings. The qualitative data were coded for themes (Marshall \& Rossman, 2016).

\section{QUANTITATIVE RESULTS}

The quantitative results indicated that participation in SoTL does impact academic instruction librarians' teacher identity. The authors ran descriptive statistics to obtain the mean scores and ran a Wilcoxon signed-rank test to discover the $p$-value, $z$-score, and effect size. Results from these tests are shown in Table 3. [Table 3 near here] The results showed that before involvement in SoTL, participants $(n=95)$ reported a mean ranking of 3.42, which falls between neutral and agree.After engagement in SoTL, participants $(n=95)$ indicated a mean ranking of 4.24 which is between agree and strongly agree. A Wilcoxon signed-rank test, which looks at the relationship between two related samples, was used to analyze the difference between the participants' scores before and after participation in SoTL (Field, 20I3).A positive $z$-score indicates participants responded with a higher mean ranking after participating in SoTL (Salkind, 20 I 7). Using SPSS, the results for this research question showed $z=6.378$, which displays a positive increase in reporting. In other words, the $z$-score showed there was positive growth in the participants' agreement of the statements on the survey after participation in SoTL.Thus, the positive growth demonstrates that SoTL positively impacted librarians' teacher identity.

There was a large effect $(r=.654)$ on the reasons participants stated for their participation in SoTL. The larger the effect size, the greater the differences between the groups (Salkind, 2017). From the $p$-value $(p=.000)$ the authors concluded there was a statistically significant difference in the responses for how the study participants felt before involvement in SoTL and after involvement in SoTL. This statistical finding indicates that engagement in SoTL impacted the teacher identity of academic instruction librarians. Owing to these findings, the null hypothesis $\mathrm{H}_{0}$ : If librarians engage in the Scholarship of Teaching and Learning, their identities will be the same as they were before, was rejected, and the research hypothesis was accepted. Participation in SoTL greatly impacted academic instruction librarians' teacher identity $(r=.654)$. After their participation in SoTL, librarians saw to a greater degree themselves as a teacher than they did prior to their involvement in SoTL $(z=6.378)$.

For each pair of items, a Wilcoxon signed-rank test determined there was a significant increase in participants' teacher identity after involvement in SoTL $(p<.001)$. This $p$-value for 


\begin{tabular}{|l|l|l|l|l|l|}
\hline \multicolumn{2}{|l|}{ Table 2. Demographics of Interview Participants } & \multicolumn{1}{|c|}{$\begin{array}{c}\text { Tnstitutional Status } \\
\text { Expength of } \\
\text { Experience }\end{array}$} \\
\hline Librarian I & Fenale & Faculty & Renewable contract & Community College & $0-5$ years \\
\hline Librarian 2 & Female & Faculty & Tenured & Regional University & $6-10$ years \\
\hline Librarian 3 & Female & Staff & N/A & Private Liberal Arts College & $0-5$ years \\
\hline Librarian 4 & Female & Faculty & Tenure Contract and will apply for tenure in next 3 years & Private Liberal Arts University & $0-5$ years \\
\hline Librarian 5 & Male & Faculty & Tenured & Research University & I6-20 years \\
\hline Librarian 6 & Female & Faculty & Tenure Contract & Regional University & $6-10$ years \\
\hline Librarian 7 & Female & Staff & N/A & Private Liberal Arts University & II-15 years \\
\hline
\end{tabular}

\begin{tabular}{|l|c|c|c|c|c|}
\hline Table 3. Survey Results \\
\hline Question & $\begin{array}{c}\text { Mean } \\
\text { Before SoTL }\end{array}$ & $\begin{array}{c}\text { Mean } \\
\text { After SoTL }\end{array}$ & P Value & Z-Score & $\begin{array}{c}\text { D Effect } \\
\text { Size }\end{array}$ \\
\hline $\begin{array}{l}\text { What is the impact of the Scholarship of Teaching and Learning } \\
\text { on academic instruction librarians' teacher identity? }\end{array}$ & 3.42 & 4.24 & .000 & 6.378 & .654 \\
\hline
\end{tabular}

\begin{tabular}{|c|c|c|c|c|c|}
\hline Question & $\begin{array}{c}\text { Mean } \\
\text { Before SoTL }\end{array}$ & $\begin{array}{c}\text { Mean } \\
\text { After SoTL }\end{array}$ & PValue & Z-Score & $\begin{array}{l}\text { D Effect } \\
\text { Size }\end{array}$ \\
\hline $\begin{array}{l}\text { I identify positively with members of the higher education teaching } \\
\text { profession. }\end{array}$ & 3.80 & 4.43 & .000 & 5.169 & .536 \\
\hline $\begin{array}{l}\text { I talk to my colleagues (librarians and other members of the higher } \\
\text { education profession) about teaching and learning questions. }\end{array}$ & 3.72 & 4.54 & .000 & 6.029 & .622 \\
\hline I identify as a teacher. & 3.63 & 4.51 & .000 & 5.801 & .602 \\
\hline I believe I am an effective educator. & 3.32 & 4.10 & .000 & 5.807 & .605 \\
\hline $\begin{array}{l}\text { Being a member of the higher education teaching profession is im- } \\
\text { portant to me. }\end{array}$ & 3.98 & 4.54 & .000 & 4.545 & .479 \\
\hline I have an accurate perception of my role as an instructor. & 3.20 & 3.99 & .000 & 5.957 & .628 \\
\hline I relate to other teachers. & 3.71 & 4.27 & .000 & 4.990 & .529 \\
\hline I attend teaching and learning conferences. & 3.21 & 4.39 & .000 & 6.198 & .664 \\
\hline When I am in front of a class, I feel as if I belong. & 3.27 & 4.21 & .000 & 6.023 & .649 \\
\hline I have a clear vision of how to become a more effective educator. & 2.85 & 3.81 & .000 & 6.315 & .685 \\
\hline I am comfortable in my role as a teacher. & 3.17 & 4.08 & .000 & 6.106 & .658 \\
\hline Other people think of me as a teacher. & 3.24 & 4.04 & .000 & 6.022 & .653 \\
\hline Other people think of me as a partner in higher education. & 3.35 & 4.10 & .000 & 5.620 & .606 \\
\hline
\end{tabular}

each survey item demonstrates the extent to which engagement in SoTL impacted academic instruction librarians' teacher identity. While the impact of SoTL is wide-ranging, there was always positive growth, as evidenced from the positive z-scores. For all items on the survey, academic instruction librarians reported significant change; thus, involvement in SoTL had a positive impact on academic instruction librarians' teacher identity. Involvement in SoTL changes how librarians see themselves. Table 4 shows a detailed view of each survey item.

From the individual survey items, results indicated a large positive effect for all survey statements (see Table 4). The positive large effect indicates that the difference between librarians' identities before participation in SoTL and after participation in SoTL was substantial.The survey item where participants reported the largest effect was for I have a clear vision for how to become a more effective educator $(r=.685)$. In other words, through participation in SoTL, study participants had the greatest change in understanding how to grow as an educator.

\section{QUALITATIVE RESULTS}

The qualitative results complemented the quantitative findings. Using NVivo the researchers conducted open coding of the in- terview transcripts to reveal themes and the main ideas in the qualitative data (Marshall \& Rossman, 2016). The codes emerged from the data until the data was exhausted. Table 5 displays the codes and the number of times the interviewees mentioned the code during the interviews.

Most interview participants indicated they had a teacher identity, two participants did not. Results also showed that when participants' felt empowered in their teaching, they identified as a teacher. Librarian 4 stated that 'it is empowering,' when others at her institution see her as a leader in teaching and learning. When outside forces impact a librarians' teaching agency, results from the qualitative interviews suggested they are less likely to see themselves as a teacher. Librarian I and Librarian 6 did not see themselves as teachers. Despite saying that teaching, 'is a large part of my job,' Librarian I also said, 'Librarians aren't seen as teachers at all.' Regarding the participation in SoTL, Librarian I continued by saying, 'It has given me tools, but I don't think it has changed my opinion of myself.' Librarian 4 saw herself as a teacher but realized others in higher education might not. When asked about her involvement in SoTL she said, it [SoTL] aids in 'having others see us as teachers. ... I don't even know how many other faculty do sometimes.' 


\begin{tabular}{|l|l|c|c|}
\hline Table 5. Interview Results & Number of Participants & Number of References \\
\hline Question & Codes & 4 & 5 \\
\hline \multirow{2}{*}{$\begin{array}{l}\text { What is the impact of the Scholarship of Teach- } \\
\text { ing and Learning on academic instruction librari- } \\
\text { ans' teacher identity? }\end{array}$} & Leadership role & 2 & 9 \\
\cline { 2 - 4 } & Not a teacher & 6 & 3 \\
\cline { 2 - 4 }
\end{tabular}

Again, participation in SoTL is linked to librarians holding a teacher identity, but only if the librarians feel empowered. Librarian 2 said,'The Scholarship of Teaching and Learning has made me see my role as a teacher as more important. I think it has added validity to that role. That this is a valuable role in the university.' Librarian 3 shared, 'I think [it] has been the real value as far as my identity and then feeling then like I had more ownership more personal ownership of that identity.' Librarian 3 also shared, 'So, I think it [SoTL] helps my identity, and that when we meet each other-meaning me and the faculty person, right-we meet as co-collaborators. So that definitely helped with my identity. I don't sort of feel like the person who has been tagged as the substitute teacher.'

The interview participants all indicated they wanted to improve in their jobs and specifically in teaching. Involvement in SoTL helped them improve, thus strengthening their teacher identity and teacher effectiveness. Those participants who were more involved in SoTL than others saw SoTL as impacting their identity to the point of adopting a leader identity. Librarian 4 stated,

I never identified as a leader, you know, but this is my thing, so now I kind of have my standing in the department because I am the person who does a lot of reading. I am kind of the go-to person, so it has kind of created a niche there- a leadership role within the department.

Overall, SoTL helped interviewees see their professional self more clearly. Librarian 2 said, 'It [SoTL] just sort of validated how I see myself and how I see this work that I am doing as important, and it has helped to have some external evidence.' She continued,

It [SoTL] has helped me see myself as an educator more fully. It has helped me to just understand the multi-faceted role or what being an educator is - a multi-faceted role ... experience or role.

Librarian 3 supported Librarian 2's observations. She noted, 'I would say it [SoTL] has been integral to my understanding of myself as a teacher.'

\section{DISCUSSION}

From the survey results, the null hypothesis $\mathrm{H}_{0}$ I f librarians engage in the Scholarship of Teaching and Learning their identities will be the same as they were before, was rejected, and the research hypothesis was accepted. Participation in SoTL had an impact on academic instruction librarians' teacher identity. Quantitative results demonstrated the significant impact of SoTL on the participants' teacher identity. After involvement in SoTL, survey participants agreed more strongly with survey items.

The quantitative findings were confirmed and explained by the qualitative data. From the interviews, the authors heard participants speak about the importance of gaining knowledge and expertise in teaching and learning because they did not always have a grounding in education prior to becoming an academic librarian. Even librarians with a background in education found involvement in SoTL beneficial in helping them see themselves as a teacher in the higher education context.

Many interview participants spoke of their involvement with the Centers for Teaching and Learning or equivalent department. Engaging in the community created by the centers impacted the identity of the librarians who participated in this study. Study participants' involvement with teaching centers helped expand their instruction skills and made them feel part of the broad teaching and learning community at their institutions. As Wenger (1998) wrote, 'developing a practice requires the formation of a community whose members engage with one another and thus acknowledge each other as participants' (p. I49). For librarians to feel completely part of the higher education teaching and learning profession, they also need to feel part of a local community that views them as teachers.

Being an outsider, or at a minimum, feeling on the outside, negatively impacts librarians' teacher identity. Thus, despite SoTL impacting teacher identities, not all participants saw themselves as teachers. In fact, two interviewees specifically said they did not see themselves as teachers. This finding supported previous research studies that found that librarians who serve in the role of instructor do not necessarily view themselves as an educator (Freedman, 20I4; Houtman, 20I0). In this study, participants indicated their view of themselves as a teacher was influenced by the situation in which they conducted their instruction. One participant felt that because they did not teach full semester courses, they were not a teacher. She often questioned if she was wanted at teaching center events because of her role as a librarian. A second participant believed that they were a professor and not a teacher. Librarian 6 described a teacher as someone who thinks about pedagogy and teaches children. The explanations for why these two interviewees did not see themselves as teachers is understood through the Communities of Practice theoretical framework. Wenger (1998) wrote that it was 'a mistaken dichotomy to wonder whether the unit of analysis of identity should be the community or the person' (p. 146). Communities in which librarians find themselves effect their views of themselves; community and individual identity are intertwined. It is difficult to tell where the individual identity ends and the community identity begins (Wenger, 1998), and since Librarian I and Librarian 6 did not believe they had colleagues who consistently viewed them as teachers, their own perceptions of themselves as teachers were compromised.

Not everyone defines the term teacher the same. Polger and Okamoto (2010) found that students viewed librarians differently and had different definitions of teacher-some definitions were narrow while others were broad. In this study, academic instruction librarians who did not see themselves as teachers were also influenced by the definitional box they created around the word teacher. For Librarian I, a teacher was someone who taught a for-credit course. For Librarian 6, a teacher was someone who thought about pedagogy over content. Even though both interviewees spent time reading teaching and learning literature, attending conferences and workshops about teaching, and 
stated they were involved in SoTL, they did not see themselves as teachers because the teaching they conducted did not fit their pre-conceived ideas of a teacher. This result might be surprising, but when considering the results through the lens of the theoretical framework, it is not. Identity parallels practice (Wenger, 1998). When the practices of librarians do not fit the community's common definition of a teacher then their identity is impacted. Similarly, identity is both local and global (Wenger, 1998). The global definition of teacher clearly influenced Librarian 6, while Librarian I was heavily influenced by the local understanding of teacher. However, identities are not one-dimensional, and as seen in the other five librarians, a teacher identity is complex and a lived experience (Wenger, 1998). All librarians had identities that spanned multiple communities of practice.

It is important to note that possessing a faculty contract is not enough evidence for librarians to consider themselves teachers. Librarian I and Librarian 6 were both considered faculty at their respective institutions but did not view themselves as teachers. On the other hand, Librarian 3 and Librarian 7 held the position of academic staff at their institutions, but they did consider themselves teachers. This finding indicates that how others in the community view librarians or how an individual views the global definition of teacher has a greater impact on teacher identity than does the institution's categorization of librarians. Furthermore, the lack of clarity concerning the role of a librarian is underscored by this finding (Freedman, 20l4).

The methods academic librarians use for instruction on information literacy varies. Various methods include a one-shot instruction session, for-credit courses, embedded information literacy, and interactions at the reference desk (Davis, 2007; Davis et al., 20 II; Roy \& Hensley, 20I6; Zai, 20I4). Librarian I mentioned that she did not see herself as a teacher because she was not with the students for a full semester. Instead, she only saw them once or twice. This finding corresponds to the results found by Davis et al. (20II): When librarians taught for-credit courses that follow the schedule of other classes taught at the institution, they were more likely to see themselves as a teacher.

These results point to the reality of how one's situation impacts one's view of him or herself. Wenger (1998) wrote that identity is influenced by community membership. The results from this study support that hypothesis of the communities of practice theoretical framework because even though all participants had teaching responsibilities, not all of them felt part of a community of higher education teachers (Wenger, 1998). Instead, they saw themselves as part of a different community or on the periphery of real teachers. In other words, participants who did not see themselves as teachers had not moved to full participation in the SoTL community and thus were not full members (Lave \&Wenger, 1991).

\section{Implications for Practice}

From this study, academic developers can conclude that Centers for Teaching and Learning, or the equivalent department, should support academic librarians' engagement in SoTL and academic development initiatives. Many participants spoke about how beneficial their university's teaching and learning center was to their professional development. Furthermore, another implication for future practice includes fostering a vision wherein academic librarians recognize each other as members of the teaching and learning community. In many instances, this is already happening, but for the broader teaching and learning community to also view librarians as participants in the community, academic librarians need to fully embrace the role themselves. Identity is negotiated, and librarians must first negotiate this identity within themselves (Wenger, 1998). In other words, the academic librarian community must first define themselves as teachers. How people refer to themselves and how they participate in a community with others impacts how they make abstract concepts such as identity concrete (Wenger, 1998).

Library and Information Science graduate programs and academic library administrations should consider openly discussing the importance of a teacher identity for effective instruction (Day \& Kington, 2008; Sammons et al., 2007). Supporting librarians in fostering their teacher identity will likely have a positive impact on the international academic librarianship community as well as the whole higher education teaching and learning community. Teaching will continue to be a job responsibility for academic librarians (Saunders, 20I5); therefore, helping them feel comfortable in that role will be beneficial. Academic developers at universities with Library and Information Science graduate programs can support the teacher identity of enrolled students.

Overall, the results of this study point to the importance of librarians being open-minded to assuming a teacher identity; librarians need to participate in the broad higher education profession. This involvement should be encouraged by academic developers, library schools, and library administrations. When librarians choose to participate in the international higher education teaching and learning community, they will have additional opportunities to engage in practices that lead to identity formation and the development of professional purpose (Wenger, 1998).

\section{LIMITATIONS AND FUTURE RESEARCH}

In this study, one limitation is the retrospective pre-post survey design. Generally, the retrospective pre-post survey design is susceptible to limitations of recall and self-reporting (Klatt \& Taylor-Powell, 2005a; Klatt \& Taylor-Powell, 2005b). Participants might have been unable to recall their identity prior to involvement in SoTL. Another limitation involves the size of the study's sample population.

Since the local community impacted the study participants, one recommendation for future research is to study librarians in a variety of international contexts. The Communities of Practice theoretical framework includes the premise that humans are social creatures, and socializing is a central part of learning. Additionally, learning impacts identity (Wenger, 1998). While connecting how humans are social beings with learning and identity, Wenger (1998) wrote about how participation in a community of practice impacts identity. Research findings supported that element of the theoretical framework. Given that, the researcher also recommends additional studies be conducted on how local communities affect academic librarians. Roxå, Olsson, and Mårtensson (2008) found that workplace culture and context shapes the identities of academicians, and research findings from the interviews indicated that faculty and staff at the research participants' institutions had a greater influence on how participants saw themselves than their institution classification. Study participants who held staff positions saw themselves as teachers, while other interview participants who were classified as faculty did not view themselves as teachers. Interview responses pointed to 
the influence of the local community on identity, which interview participants identified as including faculty members whose primary responsibility was teaching. As Julien and Pecoskie (2009) found, teaching faculty hold power over librarians. Therefore, the researcher recommends additional research to further investigate how power differentials impact the local teaching and learning community and how the power dynamic in the local community affects academic librarians' teacher identity. As previous research has shown, local events impact how a person views himself or herself (Wenger, 1998).

\section{REFERENCES}

Austin, T., \& Bhandol, J. (20/3). The academic librarian: Buying into, playing out, and resisting the teacher role in higher education. New Review of Academic Librarianship, 19(I), I5-35. http://dx.doi.org/ I 0.1080/I36 I 4533.20 I 2.740438

Battles, M. (2003). Libraries:An unquiet history. New York City, NY: Norton.

Bewick, L., \& Corrall, S. (20I0). Developing librarians as teachers: A study of their pedagogical knowledge. Journal of Librarianship and Information Science, 42(2), 97-I I0. http://dx.doi. org/10.1177/0961000610361419

Bradley, C. (2009). The Scholarship of Teaching and Learning: Opportunities for librarians. College and Research Libraries News, 70(5), 276-278.

Bryman, A. (2006). Integrating quantitative and qualitative research: How is it done? Qualitative Research, 6(I), 97-II3.

Davies-Hoffman, K.,Alvarez, B., Costello, M., \& Emerson, D. (20I3). Keeping pace with information literacy instruction for the real world:When will MLS programs wake up and smell the LILACs? Communications in Information Literacy, 7( I), 9-23.

Davis, E. L., Lundstrom, K., \& Martin, P. N. (20II). Librarian perceptions and information literacy instruction models. Reference Services Review, 39(4), 686-702. http://dx.doi. org/I0.1 I08/0090732 I I I I 86695

Davis, K. D. (2007). The academic librarian as instructor. College \& Undergraduate Libraries, I4(2), 77-101. http://dx.doi. org/I0.1300/J106v14n02_06

Day, C. (2008). Committed for life? Variations in teachers' work, lives and effectiveness. Journal of Educational Change, 9(3), 243-260. http://dx.doi.org/ 10.1007/s 10833-007-9054-6

Day, C., \& Kington,A. (2008). Identity, well-being and effectiveness: The emotional contexts of teaching.Pedagogy, Culture \& Society, I6(I), 7-23. http://dx.doi.org// 0.1080/|468|36070| 877743

Drabinski, E. (2016). Becoming librarians, becoming teachers: Kairos and professional identity. Canadian Journal of Information and Library Science, 40(I), 27-36. http://dx.doi.org//0.1353/ ils.2016.0002

Ellis, E. L., Rosenblum, B., Stratton, J. M., \& Ames-Stratton, K. (20I4). Positioning academic libraries for the future: A process and strategy for organizational transformation. Paper presented at the 35th IATUL Conference, Espoo, Finland. Retrieved from http://hdl.handle.net//808//4|4|

Field, A. (20I3). Discovering statistics using IBM SPSS statistics $\left(4^{\text {th }}\right.$ ed.). New York City, NY: Sage.

Freedman, S. (20I4). Faculty status, tenure, and professional identity: A pilot study of academic librarians in New England. Portal: Libraries and the Academy, I4(4), 533-565.

Greene J. C., Caracelli,V. J., \& Graham,W. F. (1989). Toward a conceptual framework for mixed method evaluation designs.
Educational Evaluation and Policy Analysis, II (3), 255-274.

Hensley, M. (20I5). Improving LIS education in teaching librarians to teach. In ACRL 2015 Proceedings. Paper presented at ACRL 2015, Portland, OR. Chicago, IL: American Library Association.

Hicks, D. (2016). Advocating for librarianship: The discourses of advocacy and service in the professional identities of librarians. Library Trends, 64(3), 6I5-640.

Houtman, E. (2010). "Trying to figure it out": Academic librarians talk about learning to teach. Library and Information Research, 34(I07), 18-40. Retrieved from http://www.lirgjournal.org. uk/lir/ojs/index.php/lir/article/view/246

Ivankova, N. V., Creswell, J. W., \& Stick, S. L. (2006). Using mixed-methods sequential explanatory design: From theory to practice. Field Methods, I8(4), I-8. http://dx.doi. org// 0.11 77//I525822X05282260

Julien, H., \& Genuis, S. K. (20I I). Librarians' experiences of the teaching role: A national survey of librarians. Library \& Information Science Research, 33(20 I I), I03-III. http://dx.doi. org/I0.10I6/j.lisr.2010.09.005

Julien, H., Gross, M., \& Latham, D. (2018). Survey of information literacy instructional practices in U.S. academic libraries. College \& Research Libraries, 79(2), 179-199. https://doi. org/ I0.5860/crl.79.2. 179

Julien, H., \& Pecoskie, J. (2009). Librarians' experiences of the teaching role: Grounded in campus relationships. Library and Information Science Research, 3/(3), 149-154. http://dx.doi. org/10.10 I6/j.lisr.2009.03.005

Kern, B., Mettetal, G., Dixson, M. D., \& Morgan, R. K. (20I5). The role of SoTL in the academy: Upon the 25th anniversary of Boyer's Scholarship Reconsidered. Journal of the Scholarship for Teaching and Learning, 15(3), I-14. http://dx.doi. org/ I0.14434/josotl.vI 5i3.13623

Klatt, J., \& Taylor-Powell, E. (2005a). Quick tips: Using the retrospective post-then-pre design. Retrieved from https://fyi.uwex.edu/ programdevelopment/files/2016/04/Tipsheet27.pdf

Klatt, J., \& Taylor-Powell, E. (2005b). Synthesis of literature relative to the retrospective pretest design. Retrieved from http://comm. eval.org/HigherLogic/System/DownloadDocumentFile. ashx?DocumentFileKey=3 I536e2f-4d7 I-4904-ae5d-056e32 $80 \mathrm{c} 767$

Lave, J., \&Wenger, E. (199I). Situated learning: Legitimate peripheral participation. Cambridge, UK: Cambridge University Press.

Marshall, C., \& Rossman, G. B. (2016). Designing qualitative research $\left(6^{\text {th }}\right.$ ed.). Los Angeles, CA: Sage.

Mårtensson, K., Roxå, T., \& Olsson, T. (20II). Developing a quality culture through the Scholarship of Teaching and Learning. Higher Education Research \& Development, 30(I), 5I-62. http://dx.doi.org/ I 0.1080/07294360.201 I.536972

Meyers, R.A. (2007). Report on the impact of the Scholarship of Teaching and Learning on the UW-System, I-7. Retrieved from http://www4.uwm.edu/sotl/help_support/upload/ UWS_Report_on_SoTL_impact.pdf

Perini, M. (20|4). Enhancing collaboration through the Scholarship of Teaching and Learning. Collaborative Librarianship, 6(I), 52-55.

Plano Clark,V. L., \& Ivankova, N.V. (20I6). Mixed methods research: $A$ guide to the field. Los Angeles, CA: Sage.

Polger, M. A., \& Okamoto, K. (20I0). "Can't anyone be a teacher anyway?": Student perceptions of academic librarians as 
teachers. Library Philosophy \& Practice, I- 16.

Roxå, T., Olsson, T., \& Mårtensson, K. (2008). Appropriate use of theory in the Scholarship of Teaching and Learning as a strategy for institutional development. Arts and Humanities in Higher Education, 7(3), 276-294. http://dx.doi. org/I0.1 I77//474022208

Roy, L., \& Hensley, M. K. (20I6). Helping LIS students understand the reference librarian's teacher identity. The Reference $\mathrm{Li}$ brarian, 57(4), 336-340. http://dx.doi.org// 0.1080/02763877 .2016 .1146562

Salkind, N. J. (2017). Statistics for people who (think they) hate statistics ( $6^{\text {th }}$ ed.). Thousand Oaks, CA: Sage.

Sammons, P., Day, C., Kington, A., Gu, Q., Stobart, G., \& Smees, R. (2007). Exploring variations in teachers' work lives and their effects on pupils: Key findings and implications from a longitudinal mixed-method study. British Educational Research Journal, 33(5), 68I-702. http://dx.doi.org/ I 0.2307/30032780

Saunders, L. (20I5). Education for instruction: A review of LIS instruction syllabi. Reference Librarian, 56(I), I-2I. http://dx. doi.org/I0.1080/02763877.2014.969392

Shulman, L. (2006). Forward. In T. Hatch, Into the classroom: Developing the Scholarship of Teaching and Learning (pp. vii-x). San Francisco, CA: Jossey-Bass.

Tanner, D. (20I2). Using statistics to make educational decisions. Thousand Oaks, CA: Sage.

Teddlie, C., \& Yu, F. (2007). Mixed methods sampling: A typology with examples. Journal of Mixed Methods Research, I(I), 77-I00. http://dx.doi.org/ I0.I I77/2345678906292430
Walter, S. (2005). Improving instruction:What librarians can learn from the study of college teaching. In P. Genoni \& G.Walton (Eds.), Currents and Convergence: Navigating the Rivers of Change: Proceedings of the Twelfth National Conference of the Association of College and Research Libraries, April 7-10, 2005, Minneapolis, Minnesota (pp. 363-379). Chicago, IL: Association of College \& Research Libraries.

Walter, S. (2008). Librarians as teachers:A qualitative inquiry into professional identity. College and Research Libraries, 69(I), 5 I71.

Warner, J. E., \& Seamans, N. H. (2004). Teaching centers, libraries, and benefits to both. Resource Sharing \& Information Networks, I 7(I/2), 29-42. http://dx.doi.org/I0.1300/JI2IvI7n0I_04

Wenger, E. (1998). Communities of practice: Learning, meaning, and identity. New York, NY: Cambridge University Press.

Westbrock, T., \& Fabian, S. (20I0). Proficiencies for instruction librarians: Is there still a disconnect between professional education and professional responsibilities? College \& Research Libraries, 7 I (6), 569-590.

Wheeler, E., \& McKinney, P. (20I5).Are librarians teachers? Investigating academic librarians' perceptions of their own teaching roles. Journal of Information Literacy, 9(2), I I I-128. http:// dx.doi.org/ I0.1 I645/9.2.1985

Zai, R. (20।4). Neither fish nor fowl:A role theory approach to librarians teaching. Journal of Library Administration, 55(I), I-23. http://dx.doi.org/I0.1080/01930826.2014.978680 